Rapp. Grønlands geol. Unders. 99, 51-55 (1980)

\title{
A SEDIMENTOLOGICAL INVESTIGATION OF THE CARBONATES AT THE BASE OF THE BRØNLUND FJORD GROUP (EARLY-MIDDLE CAMBRIAN), PEARY LAND, EASTERN NORTH GREENLAND
}

\author{
Peter Frykman
}

The present investigation deals with the transition from the clastic Buen Formation of Early Cambrian age to the predominantly carbonate Brønlund Fjord Group (Early-Middle Cambrian) in southern Peary Land (figs 25 and 26). These transitional sediments are defined as member A of formation 1 of the Brønlund Fjord Group (Peel, 1979, and Ineson \& Peel, this report). Member $A$ is dominated by carbonate sediments with varying clastic content and with subordinate pure clastic intercalations. It is characterised by a number of glauconitic horizons and phosphorites of various origins. These features are persistent throughout the investigated area, making this 3 to $7 \mathrm{~m}$ thick unit easily distinguishable over at least $150 \mathrm{~km}$. Member A sections were investigated during 1979 in a transect across southern Peary Land, from J. P. Koch Fjord in the west to Buen, near Børglum Elv, in the east (fig. 25). The field work in 1979 forms the basis for a detailed sedimentological investigation, especially concerned with features of early diagenetic origin and phosphatisation processes. The present account reports on some preliminary results of this investigation.

\section{Buen Formation}

In order to evaluate the character of the transition recorded in member A, the top $50 \mathrm{~m}$ of the Buen Formation were briefly investigated. In south-western Peary Land (fig. 25) this part of the Buen Formation is dominated by finely laminated shales with a minor proportion of thin sandy intercalations. Towards the east of the area both the frequency and the thickness of the sandy beds increase and, at Øvre Midsommersø (fig. 25), the sandy beds constitute approximately 50 per cent of the sequence, mainly as units less than $50 \mathrm{~cm}$ thick. Some sandstone beds display a combination of sedimentary structures such as rare sole marks, parallel lamination and small scale trough cross-bedding, which occur in a specific order somewhat reminiscent to turbidites. Further to the east, along Buen, there is a clear dominance of sandy units. These are of varying thickness, and commonly in the shape of lenticular bodies $1 / 2$ to $2 \mathrm{~m}$ thick and 10 to $20 \mathrm{~m}$ long.

Interpretation of the sedimentary regime accounting for the deposition of the upper part of the Buen Formation is not attempted, but it seems likely that the increased thickness and abundance of sand beds in the eastern part of the area indicate proximity to a source area.

\section{Brønlund Fjord Group}

The group is best developed in the area north of Adams Gletscher (fig. 25). Here the group comprises four formations and is dominated by carbonates of Early to Middle Cambrian age (fig. 26) (Peel, 1979; Palmer \& Peel, 1979; Ineson \& Peel, this report). Formation 


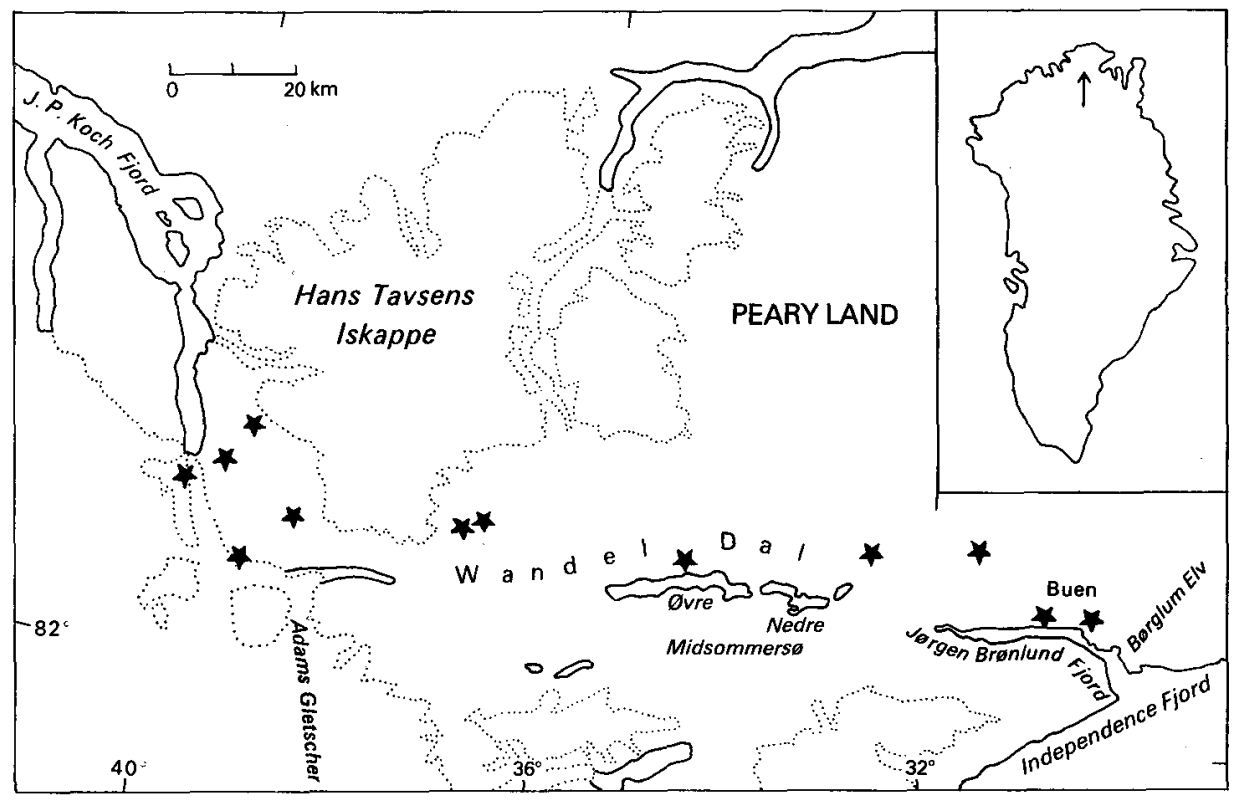

Fig. 25. Location map, showing position of member A sections visited during the field season 1979.

1 is the lowermost formation in the Brønlund Fjord Group and, with the exception of member $\mathrm{A}$, is characterised by thick sheets of dolomite breccia interbedded with thin-bedded dolomites which commonly display various states of synsedimentary deformation (Ineson, this report).

\section{Member A of formation 1}

The unit described here is referred to as member $A$ of formation 1 of the Brønlund Fjord Group (fig. 26), which occurs in southern Peary Land (fig. 1). This unit has formerly been known as member A of the Brønlund Fjord Formation (Christie \& Peel, 1977), but recent lithostratigraphic reclassification of this part of the succession has elevated the Brønlund Fjord Formation to the rank of a group (Peel, 1979; Ineson \& Peel, this report).

The carbonates of member A are mainly dolomites. Dolomitic limestones and limestones have only been recorded in a restricted area adjacent to Hans Tavsens Iskappe (fig. 25). The carbonate rocks contain different proportions of silt which decrease markedly towards the top of the member. In addition to the dominant carbonate beds, mudstones and shales occur rarely, and then in beds which are normally less than $5 \mathrm{~cm}$ thick, but which in places reach 20 $\mathrm{cm}$. They are often finely laminated and contain abundant burrows depicted by contrasting colour. Nodular texture is a common feature in member $\mathbf{A}$. This texture is distinguished by differential compaction around the nodules which indicates that lithification was caused by pre-compactional cementation.

The base of member $\mathrm{A}$ is coincidental with the first appearance of the carbonate sediments which follow the alternating sands and shales of the Buen Formation (fig. 26). 
Fig. 26. Composite stratigraphic section of Cambrian rocks in the Adams Gletscher - J. P. Koch Fjord area. Based on Peel (1979) and Ineson \& Pcel (this report).

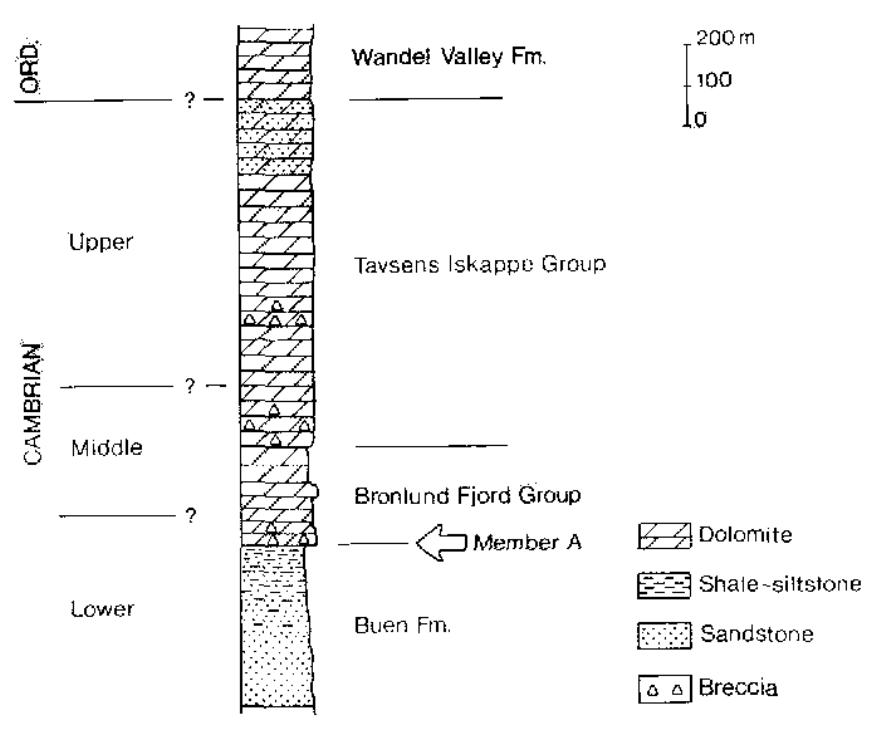

Troelsen (1949) noted that the junction is a simple erosional disconformity and that the change in character of the sediments is very abrupt, though no basal conglomerate is present. However, the present investigation indicates that, in spite of the very distinct sediment change, there is only little evidence of an erosional phase between the two formations. At a single locality at Buen a basal conglomerate rests on an eroded surface of the Buen Formation. This conglomerate comprises approximately $50 \mathrm{~cm}$ of dolomitic matrix with sand-size grains of glauconite and detrital phosphorite in addition to gravel-size clasts of sandstone derived from the underlying bed. This is the only locality so far found which displays an undoubted erosional contact.

Typically the transition from member $A$ into the subsequent strata of formation 1 is marked only by the disappearance of glauconitc and/or phosphorite. In such places the overlying beds are developed as thin-bedded to nodular, coarscly crystalline dolomites. However, in the immediate vicinity of J. P. Koch Fjord, as well as along Buen and in the Borglum Elv area, member $A$ is overlain by a breccia bed.

Gravity transport processes were presumably active in the deposition of the sand units of the Buen Formation, and, according to Ineson (this report), carbonate turbidites and carbonate debris-flows arc widespread features in formation 1 of the Bronlund Fjord Group. However, no sedimentary structures associated with such processes were recognised in member $\mathrm{A}$.

Fossils are common in member A. Mostly they are phosphatised moulds or she[l debris, but larger complete fossils such as hyolithid shells are present. Coarsely recrystallised dolomites in the upper part of member $\mathrm{A}$ are often rich in dolomitised shell fragments. The fauna of member A indicates a late Early Cambrian age (Christie \& Peel, 1977; Palmer \& Peel, 1979).

Trace fossils are present in most beds of member A. Discrete tubular burrows, 2 to $5 \mathrm{~mm}$ in diameter, occur frequently in the lower part of many sections. These burrows are appar- 
ently restricted to thick-bedded, green-grey, silty dolomites, where they form black, meandering streaks. Burrows are also indicated by contrasting colours in the thin shale units. In the dolomites slightly diffuse streaks and stringers rich in glauconite may perhaps represent indistinct burrow fills.

Glauconite and phosphorite are conspicuous elements in the carbonate lithology of member A. Glauconite occurs disseminated throughout some beds and in some distinct horizons; both forms of deposit are commonly associated with beds containing phosphoritic material. Phosphorite occurrences may be classified as follows:

(1) accumulations of phosphatised fossil moulds or phosphatic skeletal elements; in rare cases phosphatised lithoclasts may also be concentrated in conglomeratic horizons.

(2) thin phosphatised horizons. The phosphorite occurs as 1 to $10 \mathrm{~mm}$, thin, brown to black impregnations of a variety of carbonate sediments. Often such horizons have an irregular, small-scale relief (amplitude may reach 1 to $2 \mathrm{~cm}$ ) and typically the contact with the overlying sediment is very distinct. The lower termination, on the other hand, is more diffuse and with a weaker colouration of the sediment. Initial investigations of thin sections indicate that this impregnation mainly affects the fine-grained matrix and leaves most shell fragments unaltered.

The process of phosphatisation by superficial impregnation has been shown, experimentally by Ames (1959), to take place as a slow replacement of calcite by apatite. Among other conditions the process requires a non-depositional environment and available phosphate in the sea water.

In the first type of phosphorite, the internal fossil moulds bear some resemblance to examples in the English Cretaceous described by Kennedy \& Garrison (1975). In their material, the phosphatised fossil moulds result from phosphatisation preferentially affecting the somewhat indurated micritic material which formed inside fossil shells.

The phosphoritic horizons of the second type appear to have been more or less continuous sea floor surfaces which were impregnated during prolonged exposure to sea water. Their small-scale relief, which in some places shows overhangs, suggests that some lithification of the sediment may have taken place prior to erosion and exposure. These sea floor surfaces are mature hardgrounds, which, however, are infrequent in the investigated sections of member A. Incipient hardgrounds are much more abundant. These also result from early diagenetic lithification just beneath the sediment-water interface, but, in contrast to the mature hardgrounds, they have escaped subsequent exposure. Such incipient hardgrounds are distinguishable mainly by their nodular development.

Development of early diagenetic lithification is associated with low sediment accumulation rates (Jones et al., 1979) and non-deposition is essential for phosphatisation processes to work. Thus, member A appears to be a highly condensed unit with pronounced features of both low sedimentation rates and long periods of non-deposition in conjunction with local erosion. Horizons with accumulations of glauconite and phosphatised clasts may indicate periods with slight reworking of the sediment.

The condensed nature of member A can also explain why this unit - in spite of its very limited thickness - is easily recognised over all southern Peary Land. The conditions responsible for its formation were obviously widespread and indicate a regional event in the general history of the sedimentary basin. 


\section{References}

Ames, L. L. 1959: The genesis of carbonate apatites. Econ. Geol. 54, 829-841.

Christie, R.L. \& Peel, J. S. 1977: Cambrian-Silurian stratigraphy of Børglum Elv, Peary Land, eastern North Greenland. Rapp. Grønlands geol. Unders. 82, 48 pp.

Jones, B., Oldershaw, A. E. \& Narbonne, G. M. 1979: Nature and origin of rubbly limestone in the Upper Silurian Read Bay Formation of Arctic Canada. Sedim. Geol. 24, 227-252.

Kennedy, W. J. \& Garrison, R. E. 1975: Morphology and genesis of nodular phosphates in the Cenomanian Glauconitic Marl of south-east England. Lethaia 8, 339-360.

Palmer, A. R. \& Peel, J. S. 1979: New Cambrian faunas from Peary Land, eastern North Greenland. Rapp. Grønlands geol. Unders. 91, 29-36.

Peel, J. S. 1979: Cambrian-Middle Ordovician stratigraphy of the Adams Gletscher region, south-west Peary Land, North Greenland. Rapp. Grønlands geol. Unders. 88, 29-39.

Troelsen, J. C. 1949: Contributions to the geology of the area round Jørgen Brønlund Fjord, Peary Land, North Greenland. Meddr Grønland 149(2), 29 pp. 